\title{
Chinese Police Administrative Ethics Practice
}

\author{
Khamlar Sydaxay, Xiangling Wu \\ School of Politics and Public Administration, Wuhan University, Wuhan, China \\ Email: khamlar_sydaxay@hotmail.com
}

How to cite this paper: Sydaxay, K. and Wu, X.L. (2020) Chinese Police Administrative Ethics Practice. Open Journal of Social Sciences, 8, 303-315. https://doi.org/10.4236/jss.2020.81023

Received: December 30, 2019

Accepted: January 14, 2020

Published: January 17, 2020

Copyright (c) 2020 by author(s) and Scientific Research Publishing Inc. This work is licensed under the Creative Commons Attribution International License (CC BY 4.0).

http://creativecommons.org/licenses/by/4.0/

\begin{abstract}
This article first introduces the definition of police administrative ethics, puts forward the importance of police administrative ethics construction from the perspective of administrative ethics, and then improves the construction of police administrative ethics and legalization, establishes a multi-level administrative supervision mechanism, and strengthens the core values of socialism The four aspects of the police administrative ethics training mechanism and the strengthening of the Chinese publicity system to shape the police public image are four aspects of the practice of explaining the construction direction of Chinese police administrative ethics.
\end{abstract}

\section{Keywords}

Police Administrative Ethics, Legalization, Supervision Mechanism, Police Public Image

\section{Introduction}

\subsection{Definition of Police Administrative Ethics}

The term administrative ethics includes the words "administrative" and "ethics". As far as the concept of administration is concerned, it is divided into broad administrative concepts and narrow administrative concepts in terms of research scope. Professor Zhang Kangzhi believes that the broad concept of administration refers to the government's management of the entire society including itself; the narrow concept of administration refers to the internal management of the government, that is, the management of the government's own operation [1]. As far as the concept of ethics is concerned, ethics means interpersonal relationships and the theory of relationships, and refers to the order and harmony between people. Administrative ethics is not a simple graft of administrative science and ethics. Its position in the discipline includes the following three points: first, administrative ethics not only reproduces the professional ethics of 
administrative staff, but also is a moral review of administrative activities. It focuses on making the entire public administrative process, not just public administration personnel; second, the task of public administrative ethics is to analyze the value of public administrative activities; third, public administrative ethics creates a platform for the settlement of moral conflicts caused in the process of public administration [2].

To understand the connotation of administrative ethics, we must first start with the definition of administrative subjects. The subjects of administrative ethics can be divided into three categories: first, the broad subject of administrative ethics: in our country, around the division of national administrative power, a multiple administrative pattern has been formed. The Communist Party of China, the People's Government, the National People's Congress, its Standing Committee, and the People's Political Consultative Conference are all administrative ethics subjects; the second is the administrative ethics subject in the narrow sense, which refers to the ethical subjects within the narrow administrative system, including administrative organizations, executive leaders, and civil servants; the third is the special subject of administrative ethics: including the administrative system, administrative actions and public policies in the administrative system [3]. According to this, administrative ethics is about the administrative ethical values, administrative ethical principles and behavior rules of public administration systems based on justice.

It is a special ethical requirement of the public administration subject, that is, the entire administrative system [4]. This concept contains three parts of the values, principles and behavioral norms of administrative ethics. Among them, administrative ethical values are a response that people should show to public administration. They are the belief and belief in people's hearts, and the soul and core of public administration.

The basic principles and moral norms of police ethics are all codes of conduct for treating and dealing with various moral relationships in the professional activities of the police. They together constitute the criteria for selecting and evaluating the good and evil of the police's behavior. In essence, the basic principles and moral standards of the people's police are the same. Ethical principles can be said to be a broad range of norms, and moral norms are a certain range of basic principles. But there are differences between the basic principles of police ethics and ethics. The basic principle of police ethics is the highest code of conduct of the people's police with a fundamental nature. It directs and stipulates all the norms of the people's police morality. It has great generality, stability, and consistency in the people's police moral field. Police ethics is a moral code of conduct that the people's police should follow under certain conditions or within a certain range. It is a further concrete development and application of the basic principles of police ethics. Relatively speaking, it has its limitations, variability and stage.

Police administrative ethics refers to the value or moral choices made by police personnel in the face of work situations. The value choices of police officers often involve the interests of specific individuals or unspecified individuals, the 
nature of the police profession and the special role of the police make them in specific administrative. There must be a dilemma of various choices during the event. Therefore, when it is difficult to make choices in the face of conflicts between moral standards or moral values, the police must have moral and legal guidelines in order to make appropriate choices. These guidelines are the significance of police administrative ethics construction.

\subsection{Importance of Police Administrative Ethics Construction}

Strengthening the construction of police administrative ethics in China is beneficial to effectively respond to police administrative ethics anomie. It provides a preventive prescription for coping with police administrative ethics anomaly, and has a certain positive guidance and promotion effect on police responsibility administration. At the same time, strengthening the construction of Chinese police administrative ethics will help reshape the image of the police. It will help the police to effectively perform their administrative responsibilities, and it will help the police to civilize, standardize and harmonize police-civil relations.

Responsible administrative actions cannot be formed in isolation and can be effectively maintained. Favorable environmental support can promote responsible actions. In order to ensure the effective performance of police administrative responsibilities and realize responsible police administrative actions, effective integration of internal control and external control should be promoted to achieve the interaction and balance among the four elements of legal norms, supervision mechanisms, social values culture, and public image. Chinese should improve police administrative ethics by standardizing the legal system, establishing a supervision mechanism, establishing a culture of social values, and maintaining the public image of the police. Ways to Improve Police Administrative Ethics is shown in Figure 1.

This article will be based on four aspects: perfecting the construction of police administrative ethics and legalization, establishing a multi-level administrative management supervision mechanism, strengthening the police administrative ethics training mechanism with socialist core values as its core, and strengthening the Chinese publicity system to shape the public image of police. These four aspects of practice illustrate the construction direction of Chinese police administrative ethics.

\section{Regulation of Administrative Ethics through Legal Systems}

According to the investigation, the public attaches great importance to the legality and compliance of the People's Police Law Enforcement. It is necessary to regulate the police administrative ethics through the legal system. The following is the result of an investigation in Shanghai. Among the interviewees of different genders, $87.4 \%$ of the men expressed their full agreement, and $10.6 \%$ said they agreed more; $92.6 \%$ of the women said they completely agreed, and $7.4 \%$ said they agreed, and their views are more consistent. Overall, a total of $88.2 \%$ of the population fully agreed, as shown in Table 1 . 


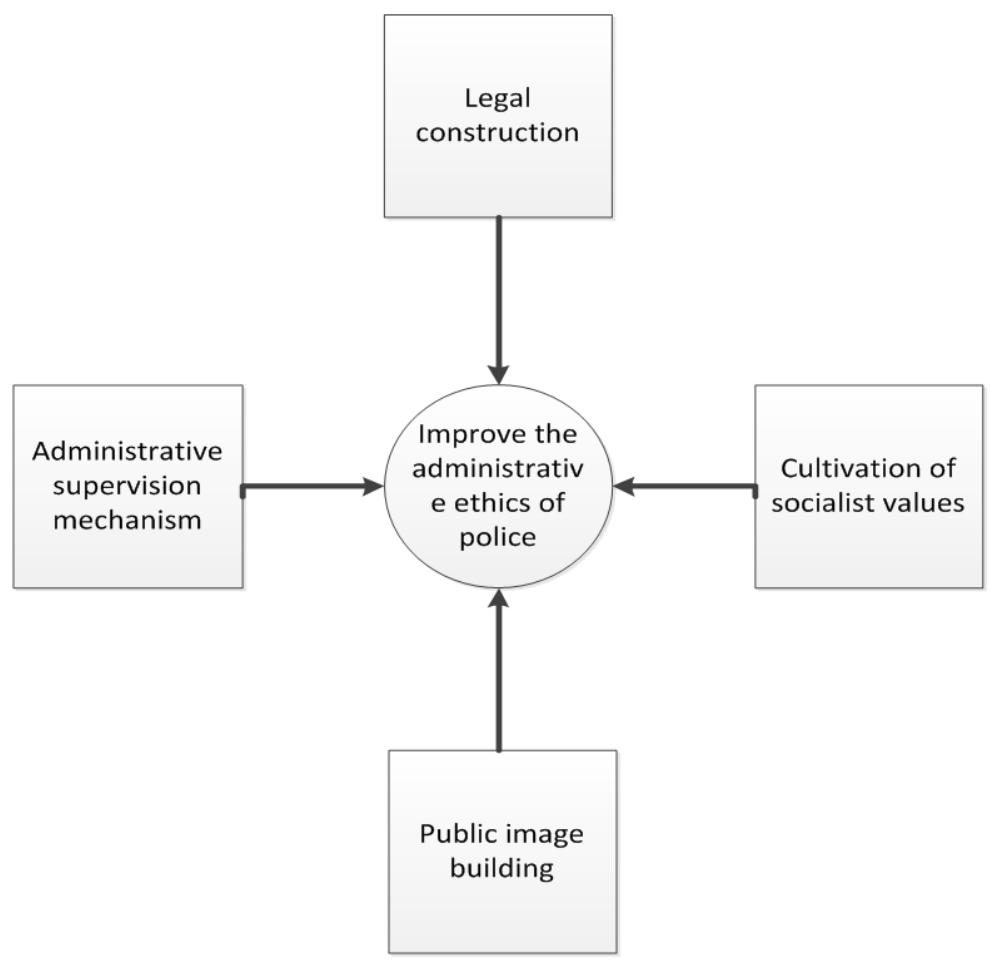

Figure 1. Ways to improve police administrative ethics.

Table 1. Police must perform various tasks within the scope permitted by law.

\begin{tabular}{|c|c|c|c|c|c|c|c|}
\hline & & & \multicolumn{4}{|c|}{$\begin{array}{l}\text { Police must perform various tasks } \\
\text { within the scope permitted by law }\end{array}$} & \multirow{2}{*}{ Total } \\
\hline & & & Don't agree & Can't tell & Comparative agree & Total agree & \\
\hline \multirow{4}{*}{ Gender } & \multirow{2}{*}{ M } & Count & 1 & 2 & 16 & 132 & 151 \\
\hline & & \%within & $0.7 \%$ & $1.3 \%$ & $10.6 \%$ & $87.4 \%$ & $100.0 \%$ \\
\hline & \multirow{2}{*}{$\mathrm{F}$} & Count & 0 & 0 & 2 & 25 & 27 \\
\hline & & \%within & $0.0 \%$ & $0.0 \%$ & $7.4 \%$ & $92.6 \%$ & $100.0 \%$ \\
\hline \multirow{2}{*}{\multicolumn{2}{|c|}{ Total }} & Count & 1 & 2 & 18 & 157 & 178 \\
\hline & & \%within & $0.6 \%$ & $1.1 \%$ & $10.1 \%$ & $88.2 \%$ & $100.0 \%$ \\
\hline
\end{tabular}

\subsection{Formulate a Unified Administrative Ethics Code}

Western countries' professional ethics legislation is relatively mature. In 1978, the United States passed the "Government Ethics Act" in light of the problems exposed by the Watergate Incident. In 1993, it issued the "Code of Ethical Conduct for US Executive Employees" [5]. Britain and France have also promulgated similar moral codes. In recent years, China has successively promulgated codes of conduct for civil servants, such as "Several Guidelines for the Honest and Clean Administration of Communist Party Members of the Communist Party of China", and the "Civil Servants Law", "Standards", "Rules for Enforcement of Public Security Organs", etc. China can learn from foreign mature experience and modify, supplement, refine and improve these existing administrative 
norms to form a system. The front-line law enforcement units of public security organs in cities and counties can also formulate effective moral implementation rules for police enforcement in the light of the actual situation of local law enforcement.

\subsection{Legislate Police Ethics}

Although China has a long history of ruling the country by virtue, it is relatively lacking in ethics and legalization. So far, China does not have a complete set of legislation to restrict the behavior of public servants. For police organizations, it is also necessary to legislate on police ethics. Under the premise of having unified administrative ethics norms, it is necessary to raise these norms to the legal level in order to confirm the effectiveness of the content of ethical norms. The author believes that the process of externalizing administrative ethical norms is ethical legislation, ensuring that the ethical norms play within the framework of the rule of law specific effects. Administrative ethics legislation is also a process of sorting out morality in society. Legalization and institutionalization of administrative ethics can allow police to clarify their legal responsibilities, locate administrative moral value orientation for police, and improve general guidance to resolve ethical conflicts. So that there is legal basis. The content of police law enforcement ethics legislation covers the entire process of police administrative law enforcement as much as possible, including: one is that the law enforcement activities carried out by police must comply with the code of ethical behavior; the other is the education and supervision of police morals; the third is the violation of police law activities Provisions for the punishment of ethical behavior; the fourth is to make restrictions on certain specific activities of departing employees during a specific period of time after separation, which is a method generally adopted in countries with a more sound western rule [6].

As a kind of external control, the construction of police ethics and legal system is objectively binding. The control factors come from outside the police themselves. Police ethics legislation and the institutionalization of police ethics not only provide the toughest external guarantees for ethics construction, but also provide police with the correct administrative value orientation and value orientation, and provide general guidance for the resolution of ethical conflicts. Legislation is the identification of the basic moral concepts of society. Therefore, the legalization and institutionalization of police administration is an inevitable law to ensure the realization of ethics.

\section{Establish a Multi-Level Administrative Supervision Mechanism}

\subsection{Establish Police Ethics Supervision Agency}

In the construction of administrative ethics at the government level in developed countries, ethics supervision institutions with strong independence have been established. For example, the United States has established an ethics office in the 
federal government, and ethics offices or ethics committees in parliaments and governments of states and cities. The agency's cabinet has a general oversight office [7]. The ethical supervision agencies in developed countries generally have high specifications, and have strong independence in personnel management and funding guarantees. They have played a role in preventing and supervising administrative ethics anomalies. China does not currently have an administrative ethics supervision agency with clear functions. Generally speaking, the organization department is responsible for the background review of civil servants and investigations on individual morality and administrative ethics; the discipline inspection and supervision department is responsible for punishing civil servants who have problems with individual morality and administrative ethics; in the daily management and training of civil servants, There is no mechanism for administrative ethics training of civil servants by a unified ethics agency. If we want to solve the administrative ethics supervision of the police in China, we can try to set up a police ethics supervision committee, which is responsible for the police administrative ethics legislation, and is responsible for the deployment and implementation of the law. The Police Ethics Supervision Committee should focus on the ethical supervision of the decision-making and implementation of police organizations, and implement dynamic monitoring of the individual character of police officers. At the same time, it is responsible for accepting complaints, feedback and appeals on police administrative ethics. According to the independent, professional, and objective construction concept, national ethics supervision committees, provincial police ethics supervision committees (including public security bureaus of the municipalities directly under the Central Government and provincial public security departments, etc.) and city and county police ethics supervision committees The three-level construction model (including prefecture-level cities, county-level cities, counties directly under the provincial government, and other ordinary counties) is used for management-level construction. The Ethics Supervision Committee is not managed by a parallel public security agency, and implements top-down vertical management. The personnel and financial rights of this agency are independent of the local government and are fully guaranteed by the central government. The police ethics monitoring committee has a presence in various places. The members of the Police Ethics Supervision Committee may be full-time or part-time. The members can be basically divided into the category of police specialists (industry experts engaged in police research, research fields or affecting the police, with certain titles and academic qualifications), police employment (with police status, and engaged in police occupations to reach a certain working life, Good word-of-mouth industry model or typical representative) and social public category (ethical self-disciplined person with a certain degree of knowledge or knowledge and experience, judgement objective and fair). Members can be included in the police ethics supervision committee member database after being selected through qualification examinations according to certain criteria (knowledge, body, beliefs, conduct, etc.). The update and maintenance of the database 
is implemented by the government and entrusted by a third-party qualified organization. All members' information is open to the public and is subject to supervision from all walks of life. Once members of the committee are found to have violated the law, violated the law, abused their duties, leaked secrets, or violated the legal rights and interests of others, they will be severely punished, removed from the database, and blacklisted to maintain the committee members, purity, morality, fairness and impartiality. According to the members' subjective area selection and specific composition ratio principles, a random selection method is adopted to form the grass-roots police ethics supervision committees, thereby ensuring the objective and impartiality of ethics supervision committee members in ethical supervision, and the possible interests and the position was reduced to a minimum. The committee will perform the following duties: First, it will improve police administrative ethics legislation. The second is to conduct ethical supervision and assessment of police organizations and individual police officers in accordance with the law. The third is to accept reports and complaints from police administrative ethics parties, as well as defend rights and complaints. Fourth, establish a personality assessment file for police officers, and provide recommendations for personality investigations in accordance with legal procedures and confidentiality levels in accordance with reasonable applications within relevant police organizations.

\subsection{Carry Out Dynamic Monitoring of Police Character}

The Police Ethics Supervision Committee is responsible for establishing a personal character file for each police officer upon entry. Pre-employment character survey can take the form of consulting files, field interviews, interviews with related parties, etc., to show the individual personality literacy of police individuals before they enter employment, personal appearance, personal examination, financial loans Such integrity conditions and character evaluations from teachers, classmates or leaders and colleagues are objectively documented. After entering the post, the ethics supervision committee should take the form of explicit inspection and unannounced visits, and conduct interviews with leaders of the higher-level departments of the police unit or staff, training teachers, colleagues and close-knit peers, subordinates, administrative service targets, and crackdown personnel. The content of the interview should be recorded and investigated to verify, and strive to have a comprehensive grasp of the individual police's legal literacy, living style, financial status, marital status, mental status, psychological status and so on. After the police ethics supervision committee has mastered the basic data for verification, it conducts a reasonable analysis and gives the police individual a more objective and fair personality evaluation. Each character determination conclusion must have factual basis and judgment standards. The personal character files of the police are updated by the ethics monitoring committee and kept confidential. When assessing individual police work, in accordance with relevant procedures, the Police Ethics Supervision Committee, after approving an application from an assessment organization, will provide a more 
detailed assessment report of individual police personality. The report is included in the corresponding level of confidentiality and will not be made public to individual police officers and other unrelated personnel being evaluated. The personality assessment report of the police will have an important impact on the overall evaluation of the individual police work.

\section{Training Mechanism: The Core Values of Socialism}

\subsection{Improve the Police Administrative Ethics System}

First, improve the administrative ethics training system. Establish a unified independent ethics training institution to provide police with administrative ethics training. Administrative ethics training can continue to strengthen police professional identity, clear role positioning and belief pursuit through various forms such as industry model appearances, specific case analysis education, expert lectures, knowledge contests, job training, and exchange meetings attended by multiple subjects. Establish correct administrative ethical values, follow professional ethics in accordance with police administrative responsibilities, cultivate ethical autonomy, improve moral self-discipline, and enhance the administrative ethical awareness and ethical decision-making level of individual police officers. For example, in the process of law enforcement by traffic police, traffic order managers, traffic participants (including motor vehicle drivers, non-motor vehicle drivers, pedestrians, etc.), traffic offenders, etc. understand the traffic police's handling principles, handling methods, and handling opinions. Often different, traffic policemen will also be subject to conflicts of administrative responsibility due to interference from social factors and other factors. Through administrative ethics training, when facing the administrative ethics dilemma, the traffic police can adhere to the principled stance on the one hand, and carry out correct evaluation on the other hand, actively meet the reasonable expectations of the society, and use appropriate methods to creatively complete various tasks.

Second, improve the administrative ethics assessment system. The police ethics assessment system should be rationally improved in the recruitment, training, promotion, and promotion of police ranks. While attaching great importance to police professional skills and business literacy, more attention is paid to the personality, moral sentiment, and ethical autonomy of the police. Only by being comprehensive and objective can the police be trained to achieve both morality and integrity, and maximize the protection of public interests. For example, in Australia, during the police recruiting training session, conduct evaluation is incorporated into the assessment and management of trainees [8]. Conduct evaluation is not an independent assessment subject, but implements the overall recruitment training link. Training police officers who have serious conduct problems or multiple minor conduct problems will be rejected by one vote, and minor conduct problems will leave stains in the comprehensive evaluation file. The US Police Academy incorporates values or professional ethics requirements into the overall training plan during police pre-service training. 


\subsection{Integrate Core Socialist Values into Police Administrative Ethics Education}

Socialist core values are the core of the socialist core value system, reflecting the rich connotation and practical requirements of the socialist core value system. Since the 18th CPC National Congress, the central government has attached great importance to the cultivation and implementation of core values of socialism and the cultivation of core values of civil society. Good social atmosphere and social and cultural atmosphere, can give police responsible administration with strong external social environment support. In the process of participating in the public life of society, individual citizens should possess the social and ethical qualities of the society or the outstanding social virtues with public demonstration significance that are actually displayed. The ethical qualities that the police should possess in the process of administrative law enforcement include civility, courtesy, justice, social responsibility, equality, tolerance, integrity, gratitude, compassion, mutual assistance, kindness, patriotism, humanitarianism, and internationalism.

The core values of socialism embody a kind of social ethics in the public domain of society, and play an important role in the construction of democracy, civilization and the rule of law in modern society. For society, the realization of the inherent benefits of public administration requires public administrators who possess virtues. The cultivation of police virtues can be strengthened through the following reasonable paths: one is to strengthen the consciousness education of police administrative ethics and socialist core values; the other is to strengthen the education of socialist core values at various levels and various administrative personnel; the third is to strengthen society Practice core education of core values.

\section{The Formation of the Public Image of the Police in China's Publicity System}

\subsection{Defend Police Law Enforcement Authority}

As a law enforcer, the police should have absolute law enforcement authority in the process of law enforcement. Achieving the rule of law in police affairs cannot be achieved by weakening police law enforcement powers and security control functions, let alone sacrificing the police's legitimate rights and interests [9]. Police law enforcement authorities must not be provoked in any way. Law enforcers are the defenders of the legal order. Especially for the police, police power itself has the characteristics of violence and coercion. If you ignore the power of police, you will blindly emphasize the service and restraint of the police and violate the lawful rights and interests of the police. There will be more cases of assault and police, and the dignity of the law will be tarnished. Only when the legitimate rights and interests conferred by the law of the police themselves are effectively guaranteed and maintained, and the police's own security concerns are eliminated, can the police effectively perform their administrative responsibili- 
ties. In specific practice, the crime of assaulting a police officer, constructing an exclusive system of police uniforms, improving the right to use police equipment and equipment, establishing scientific evaluation standards for police behavior, and clarifying the legal and institutional requirements of police law enforcement authority are the legitimate rights and interests of police officers. Provide legal and institutional guarantees [10]. At the same time, it is necessary to strengthen law popularization and publicity and guidance, increase the crackdown on contempt for police law enforcement authority, infringe on the legitimate rights and interests of police, and strengthen the legalization and professionalization of the police force itself, and regulate police law enforcement behavior.

\subsection{Understand Respect for the Police Profession}

Consciously safeguard the legitimate rights and interests of the police. The protection of the lawful rights and interests of the police requires not only the necessary guarantee from the legal level, but also the effective support from the social ethics aspect. The whole society and all citizens give the police profession full respect, understanding and support. The police occupation is the most dangerous occupation in peacetime. The high-intensity, difficult and wide-ranging police work makes the police practitioners under tremendous pressure psychologically, and their mental and physical health conditions are worrying. If society can be more tolerant, use a peaceful, rational and fair attitude to view and objectively evaluate the police group, and build a good social ethics, can we effectively safeguard the legitimate rights and interests of the police, and avoid the tragic events of bloodshed, sweat and tears.

\subsection{Reasonable Response to Police-Related Public Opinion}

First, strengthen the positive energy orientation of media propaganda. Police power is public power and is in a strong position; citizenship power is private power and is in a weak position. Public power should be subject to supervision and questioning by the media, and private power should be fully respected and guaranteed, but police power and citizenship are not completely opposed. Police power and citizenship are opposites and unified. Too much restraint on police power will make publicity excessive, and too much to show police power will also cause excessive suppression of citizenship. A society ruled by law pays more attention to reconciling the balance between the two. Police power should be subject to reasonable public opinion supervision. However, public opinion supervision must adhere to the principles of objectivity, impartiality, comprehensiveness, and accuracy, and must not be of interest or inclination. At the same time, supervision must form a closed loop, and supervision of public opinion must be matched with effective supervision measures. While the media assumes responsibility for the supervision of police power, should also assume the necessary social responsibility. For the public opinion of hot police, we must stand on the overall perspective, maintain a peaceful and rational attitude, report the 
truth of the facts objectively and impartially, and convey a positive energy direction. Make false reports without the truth, or use the media's resource advantages and connections to make subjective stance-oriented comments, or deliberately welcome the masses of low-level interest in a short period of time to report a large number of similar types of negative police-related information. The media magnifies local small problems into overall problems, giving the audience an illusion, misunderstanding the police, and aggravating the confrontation between the public and the police. In a sense, it is a violation of the overall image of the police and the credibility of police enforcement. Irresponsible media propaganda actions may be used by interest groups who want to evade, which is not conducive to the transmission of positive social energy, and will lead to the instigation and destruction of social law and order by human factors.

Second, improve the police-related public opinion response mechanism with a third party as the main responsibility. It is necessary to improve the police-related public opinion emergency plan, establish a police-related public opinion response agency led and responsible by third-party agencies, and improve the authoritative response mechanism. In the face of police-related public opinion that has a high degree of social concern or influence, it is necessary to promptly release authoritative information to actively respond to reasonable questions from all walks of life in society, and to respond to social concerns, based on objective facts and verified evidence. The report must be objective, comprehensive, truthful, and credible, neither bragging about the issue nor concealing it.

Third, we must crack down on malicious speculation. At present, because online reviews do not implement a real-name system, irresponsible remarks that run counter to objective facts exist in a virtual society. The legislature should introduce virtual social management and supervision measures as soon as possible, implement the real-name system requirements for online reviews as soon as possible, and increase the illegal costs of spreading rumors, spreading rumors, malicious publicity hype, publishing insulting, intimidating speech, and other illegal acts, through standardized management and severe crackdowns, To further purify the virtual public opinion environment. For the supervision of public opinion, it is necessary to give full play to the legal supervisory role of public opinion and fully safeguard the legitimate rights and interests of each citizen, but not to allow public opinion to become the dominant factor that interferes with judicial justice and protect the lawful authority of law enforcement authorities and law enforcement personnel.

Fourth, strengthen procedural awareness and the idea of the rule of law. With the development of society, the awareness of citizens' rights is increasingly awakened, and the enthusiasm and extensiveness of public participation are conducive to the process of democratization. But in a society ruled by law, democracy is not pan-democracy, and all actions need to be regulated within the framework of the rule of law. Any investigation and verification of police-related public 
opinion needs to be conducted in accordance with legal procedures under the rule of law. Subjective assumptions that are not based on factual truth and objective evidence, the ideal logic that the special interest group overrides the rule of law by the rule of man over the law is not desirable. The formation and cohesion of the rule of law requires the concerted efforts of the entire society.

\section{Concluding Remarks}

Police administrative law enforcement involves all aspects of society. This article only starts from the construction of police's own administrative ethics, and illustrates several directions for the construction of police administrative ethics. However, the construction of police administrative ethics also depends on the support of citizens and other administrative organizations. It is also important to improve the administrative ethics of other administrative organizations. Administrative ethics exists not only in the police industry, but also in other administrative industries such as education, health, urban management, and planning. According to the role construction of different administrative industries and the inner conscience of administrative subjects, there are commonalities and differences between objective administrative responsibilities and subjective administrative responsibilities in each administrative industry, and administrative personnel in each administrative industry also needs to effectively perform administrative responsibilities in the administrative process. In daily administration, we cannot unilaterally emphasize the administrative ethics of the police industry, and ignore or despise the administrative ethics of other administrative industries. We must not only standardize the common administrative ethics that administrative personnel should have at the government level, but also start with the characteristics of the industry and combine government. The unified norms at different levels consolidate administrative ethics that are in line with the characteristics of their respective administrative industries. The simultaneous follow-up of the construction of administrative ethics in other administrative organizations can not only improve the administrative efficiency of the government, increase public satisfaction with the government, but also optimize the social supportive environment for police responsible administrative actions.

\section{Acknowledgements}

Thanks to my teacher and my classmates.

\section{Conflicts of Interest}

The authors declare no conflicts of interest regarding the publication of this paper.

\section{References}

[1] Moriya, S., Miki, Y., Kanagaki, M., Yamamoto, A. and Ishikawa, M. (2011) Evaluation of Cartilage Surface Injuries Using 3d-Double Echo Steady State (3d-Dess): Effect of Changing Flip Angle from 40 to 90. Acta Radiologica, 52, 1138-1142. https://doi.org/10.1258/ar.2011.110275 
[2] Alexander, J. and Stivers, C. (1995) An Ethic of Race for Public Administration. Administrative Theory \& Praxis, 32, 578-597. https://doi.org/10.2753/atp1084-1806320405

[3] Zhang, Q.L. and Zhang, Q.-L. (2006) The Spirit of Public Administration. Journal of Changsha University, 20, 83-85.

[4] Du, J.F. (2011) Requirement of the Public Administration Subject. In: Police Ethics, 3rd Edition, Chinese People's Public Security University Press, Beijing.

[5] Deng, G.L. (2017) Government Ethics Ac. In: Analysis of the Preface of Police Law Enforcement, 4th Edition, Chinese People's Public Security University Press, Beijing.

[6] Chen, D.W. (2016) Research on Advancing the Construction of the Government of the Rule of Law in China. Journal of Tianjin Administration Institute, 18, 71-80.

[7] Zheng, Z.L. (2011) Agency's Cabinet. In: Administration Science, 3rd Edition, Higher Education Press, Beijing, 346.

[8] Cui, H.Y. (2011) Management and Enlightenment of Trainees in Overseas Police Education and Training. Police Education, No. 7, 71-77.

[9] Cooper, T.L. (2010) Administrative Ethics. In: A Way to Realize Administrative Responsibility, 2nd Edition, Renmin University of China Press, Beijing, 78-79.

[10] Frederick, W.So. (2013) Legal and Institutional Guarantees. In: The Spirit of Public Administration, 3rd Edition, Renmin University of China Press, Beijing, 26-28. 